\section{Critical Yellow Nutsedge-free Period for Polyethylene-mulched Bell Pepper}

\author{
Timothy N. Motis ${ }^{1}$ and Salvadore J. Locascio \\ University of Florida, Institute of Food and Agricultural Sciences, \\ Horticultural Sciences Department, 1251 Fifield Hall, PO Box 110690, \\ Gainseville, FL 32611
}

\section{James P. Gilreath \\ University of Florida, Institute of Food and Agricultural Sciences, Gulf Coast Research and Education Center, $500760^{\text {th }}$ Street East, Bradenton, FL 34203}

Additional index words. Capsicum annuum, competition, Cyperus esculentus, interference, methyl bromide

\begin{abstract}
Yellow nutsedge (Cyperus esculentus L.) interference with bell pepper (Capsicum annuum L.) has become an important concern because of the phase-out of methyl bromide as a soil fumigant. The critical period for yellow nutsedge control in pepper was determined in two adjacent experiments (removal and plant-back) conducted twice in separate fields each Spring and Fall 2000 in Gainesville, Fla. In the removal experiment, nutsedge was planted with pepper in all but the full-season (13 weeks) weed-free controls and removed at 1,3,5, and 7 weeks after pepper transplanting (WAPT). Full-season weedy control plots in the removal experiment were obtained by never removing nutsedge planted with pepper ( 0 WAPT). In the plant-back experiment, all but the full-season weed-free controls received nutsedge with nutsedge planted at 0 (full-season weedy control), 1, 3, 5, and 7 WAPT. Sprouted nutsedge tubers were planted at a density of 45 tubers $/ \mathrm{m}^{2}$. Results indicated that a nutsedge-free period from 3 to 5 WAPT in spring and 1 to 7 WAPT would prevent $>\mathbf{1 0} \%$ yield reductions of large and marketable peppers. Full-season nutsedge interference reduced pepper yields by $>70 \%$. When planted with pepper, nutsedge shoots grew taller than pepper plants with nutsedge heights at 5 WAPT up to two times greater in fall than spring. Results indicated that yellow nutsedge control practices should be initiated earlier and continue longer in fall than spring due to faster early-season nutsedge growth in fall than spring.
\end{abstract}

Bell pepper, valued at $\$ 234$ million in 1999 to 2000 , ranks second to tomato in total value of Florida vegetables (Witzig and Pugh, 2001). Polyethylene mulches used in vegetable production are easily penetrated by leaf tips of yellow (Cyperus esculentus) and purple (Cyperus rotundus $\mathrm{L}$.) nutsedges (Chase et al., 1998). Season-long yellow nutsedge interference with a planted population of 90 tubers $/ \mathrm{m}^{2}$ reduced spring-grown bell pepper yields by at least $70 \%$ (Motis et al., 2003). Full-season purple nutsedge interference reduced okra (Hibiscus esculentus L.) and tomato (Lycopersicon esculentum Mill.) yields by $62 \%$ and $53 \%$, respectively (William and Warren, 1975).

Yellow nutsedge reproduces primarily by underground tubers, each of which may produce up to seven shoots (Tumbleson and Kommedahl, 1961). Buds on a tuber may sprout at different times (Stoller et al., 1972), enabling some tubers to escape the effects of applied chemicals. Methyl bromide applied under polyethylene mulch controls nutsedges,

\footnotetext{
Received for publication 14 Feb. 2003. Accepted for publication 30 Sept. 2003. Research supported by the Florida Agricultural Experiment Station and approved for publication as journal series R-09471. This paper is a portion of a dissertation submitted by T.N. Motis in fulfillment of a $\mathrm{PhD}$ requirement. ${ }^{1}$ Current address: Educational Concerns for Hunger Organization, 17391 Durrance Rd., N. Fort Myers, FL 33917.
}

but it is being phased out of production in the United States due to its alleged contribution to the depletion of the stratospheric ozone layer (Environmental Protection Agency, 1999). Herbicides labeled for use in pepper do not have strong activity against nutsedge. Therefore, yellow nutsedge management in bell pepper production is a concern.

The critical nutsedge-free period has been determined for several vegetables. The critical purple nutsedge-free period was between 3 and 5 and between 3 and 7 weeks after crop establishment for tomato and okra, respectively (William and Warren, 1975). The critical yellow nutsedge-free period for $10 \%$ loss of marketable yield of tomato was between 3 and 6 weeks after crop planting (Morales-Payan, 1999). Information on the critical period for yellow nutsedge interference with bell pepper is lacking. This research was conducted to determine when during a growing season that yellow nutsedge control is most critical for acceptable fruit production (no more than $10 \%$ loss).

\section{Materials and Methods}

Trials were conducted in Spring and Fall 2000 at the Horticultural Research Unit of the University of Florida in Gainesville, Fla. During Spring 2000, one field was comprised of Kanapaha fine sand (loamy siliceous, hyperthermic, Grossarenic Paleaquult) and the other of Arredondo fine sand (loamy, siliceous, hyperthermic, Grossarenic Paleudult). In Fall 2000, the soil in both fields was an Arredondo fine sand. Each of the four trials were conducted in separate fields with the two fields in each season located in different (non-adjacent) areas of the farm.

Within each field, two single-factor experiments (removal or plant-back) were conducted adjacent to each other. Treatments in the removal experiment were nutsedge removal times of 0 (full-season weed-free; no nutsedge planted), 1, 3, 5, 7, and 13 (full-season interference; no planted nutsedge removed) weeks after pepper transplanting (WAPT). Treatments in the plant-back experiment were nutsedge planting times of 0 (full-season interference), $1,3,5,7$, and 13 (full-season weed-free; no nutsedge planted) WAPT. Treatments were arranged in a randomized complete-block design and replicated five times.

Beds (6.1 m long with 0.61-m-wide tops) were formed on 1.2-m centers, fumigated with $392 \mathrm{~kg} \cdot \mathrm{ha}^{-1}$ of 75 methyl bromide : 25 chloropicrin injected $20 \mathrm{~cm}$ deep with two shanks to control soil-borne pests, including existing nutsedge tubers, and covered with polyethylene mulch. Simultaneously with soil fumigation, micro-irrigation (drip) biwall tubing (Chapin Watermatics Inc., Watertown, N.Y.; emitter spacing of $30 \mathrm{~cm}$; orifice diameter of $0.025 \mathrm{~cm}$; flow rate per min of $1.89 \mathrm{~L} / 30.5 \mathrm{~m}$ ) was placed on the soil surface in the middle of each bed and covered with polyethylene mulch (Sonoco, Hartsville, S.C.; $0.0038 \mathrm{~cm}$ thickness; black in spring, white in fall).

Planting holes were punched on 23 Mar. in spring and 16 Aug. in fall within 1 to 2 weeks after fumigation. Holes for pepper transplants were punched with a planting wheel to form double rows of holes spaced $31 \mathrm{~cm}$ apart in the rows with $31 \mathrm{~cm}$ between the two rows. Holes for nutsedge tubers were punched on the bed-tops via a board with dowels $(7.6 \mathrm{~cm}$ long and $2 \mathrm{~cm}$ wide) screwed to the underside. Dowels were equally spaced $15 \mathrm{~cm}$ apart to create a density of 45 tubers $/ \mathrm{m}^{2}$, respectively. This density was chosen based on the previously determined yellow nutsedge density above which little or no further crop yield loss occurred (Motis et al., 2003). All plots received nutsedge planting holes so results would not be influenced by the presence or absence of holes.

Nutsedge tubers were presprouted in a greenhouse in trays filled with potting soil (Fafard Mix No. 2; V-J Growers Supply; Apopka, Fla.). Bell pepper ('X3R Camelot') seedlings and sprouted nutsedge tubers, with $\approx 9$-cm tall leaves, were transplanted to field plots on the day planting holes were punched. At pepper planting time ( 0 WAPT), all but the full-season weed-free control (WFC) plots in the removal experiment received nutsedge tubers; in the plant-back experiment, nutsedge tubers were planted at 0 WAPT for the full-season weedy control. Each nutsedge planting hole received one tuber and associated shoot(s). At 1, 3, 5, and 7 WAPT, nutsedge plants were either planted (using presprouted tubers as described above) or removed according to treatments. Nutsedge 
Table 1. Model equations obtained by regressing pepper yield percentages (of yield in full-season weed-free controls) against times after pepper planting that nutsedge was either removed or planted.

\begin{tabular}{|c|c|c|c|c|c|}
\hline No. & Season & Nutsedge treatment & Equation $^{2}$ & $r^{z, y}$ & $\mathrm{CV}^{\mathrm{y}}$ \\
\hline \multicolumn{6}{|c|}{ Large fruit } \\
\hline $2^{\mathrm{w}}$ & Fall & Removal time & $\mathrm{Y}=1.37+97.3 /\left(1+\mathrm{e}^{(-(\mathrm{X}-3.25) /-0.645)}\right)$ & 0.81 & 54.8 \\
\hline $3^{\mathrm{w}}$ & Spring & Planting time & $\mathrm{Y}=25.9+67.2 /\left(1+\mathrm{e}^{(-(\mathrm{X}-3.34) / 0.641)}\right)$ & 0.85 & 19.5 \\
\hline \multicolumn{6}{|c|}{ Marketable fruit } \\
\hline $5^{\mathrm{w}}$ & Spring & Removal time & $\mathrm{Y}=28.2+70.7 /\left(1+\mathrm{e}^{(-(\mathrm{X}-4.90) /-0.608)}\right)$ & 0.85 & 22.8 \\
\hline $6^{\mathrm{w}}$ & Fall & Removal time & $\mathrm{Y}=2.21+94.6 /\left(1+\mathrm{e}^{(-(\mathrm{X}-3.57) /-0.843)}\right)$ & 0.92 & 30.2 \\
\hline
\end{tabular}

${ }^{2}$ These sigmoidal equations were used to plot the slopes in Fig. 1. Equations were developed with data averaged over the two fields used each season.

${ }^{\mathrm{y}}$ Coefficients of determination $\left(r^{2}\right)$ and variation (Cv) were obtained by regression of data within means. Values for $r^{2}$ indicated fitness of data to regression lines while those for $\mathrm{CV}$ indicated variation of values (10 per mean) from the means.

${ }^{\mathrm{x}}$ Equation (no. 1) followed the form of $\mathrm{Y}=\mathrm{a} /\left(1+(\mathrm{X} / \mathrm{x} 0)^{c}\right)$ where $\mathrm{Y}=$ yield percentage; $\mathrm{a}=$ maximum predicted value of $\mathrm{Y}$; $\mathrm{X}=$ weeks after crop establishment; $\mathrm{x} 0=$ value of $\mathrm{X}$ corresponding to $50 \%$ of $\mathrm{a}$; and $\mathrm{c}=$ constant.

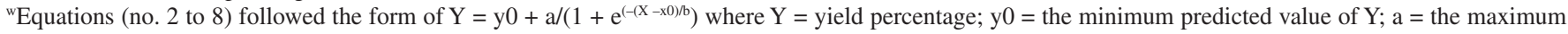
predicted value of $\mathrm{Y}$ minus $\mathrm{y} 0 ; \mathrm{e}=$ exponent; $\mathrm{x}=$ weeks after crop estabishment, and $\mathrm{x} 0$ and $\mathrm{b}$ were parameters that defined portions of the lines corresponding to the lower limits of Y. Maximum Y equaled "y0" plus "a".

was not planted in the full-season WFC plots in the plant back experiment. Nutsedge plants in the removal experiment were pulled from their holes by hand, removing both shoots and roots, with care taken not to disturb the pepper plants and polyethylene. Shoots of planted nutsedge seedlings were allowed to proliferate throughout the season or until the appropriate removal time. Pepper and nutsedge plants that did not survive initial transplant were re-planted during the first and second WAPT.

In each trial, the soil received $224 \mathrm{~N}-37 \mathrm{P}-$ $186 \mathrm{~K} \mathrm{~kg} \cdot \mathrm{ha}^{-1}$ with all $\mathrm{P}$ and $40 \%$ of $\mathrm{N}$ and $\mathrm{K}$ preplant-incorporated before mulch application. The remainder of $\mathrm{N}$ and $\mathrm{K}$ in each trial was drip-applied in 10 equal weekly applications beginning at 1 WAPT. Water was supplied daily through the micro-irrigation tubes prevent moisture stress to plants. Pesticides including bacillus thuringiensis (subsp. aizawai or var. kurstaki), cyromazine, esfenvalerate [(S)cyano (3-phenoxyphenyl) methyl(S)-4-chloroalpha-(1-methylethyl) benzeneacetate], maneb (manganese ethylenebisdithiocarbamate), and permethrin [(3-phenoxyphenyl)methyl ( \pm ) cis-trans 3-(2,2-dichloroethenyl)-2,2dimethylcyclopropanecarboxylate] were applied according to University of Florida recommendations for control of insects and fungal diseases (Maynard et al., 2002).

Heights of representative plants were recorded when nutsedge was planted or removed. Pepper plant height, the distance from the bed surface to the highest bud, was obtained from four plants per plot. Nutsedge shoot height was obtained by measuring the distance from

Fig. 1. Interaction of season (2000) and yellow nutsedge interference time with pepper before nutsedge removal (----) or of season and nutsedge-free time before planting (-) nutsedge into pepper plots on large and marketable bell pepper weight. Data were averaged over both fields each season. Slopes were generated by regressing data $(\mathrm{n}=10)$ within means (data points shown). Models were sigmoidal and significant at $P \leq 0.001$. Critical nutsedge-free periods for $10 \%$ yield loss (equivalent to $90 \%$ of yield with no nutsedge) were indicated by vertical lines that were solid for the spring or dashed for the fall season. See Table 1 for equations. the bed surface to the highest growing point of eight leaf blades per plot.

Peppers were harvested on 9 and 21 June in spring and on 6 and 15 Nov. in fall. Fruit were

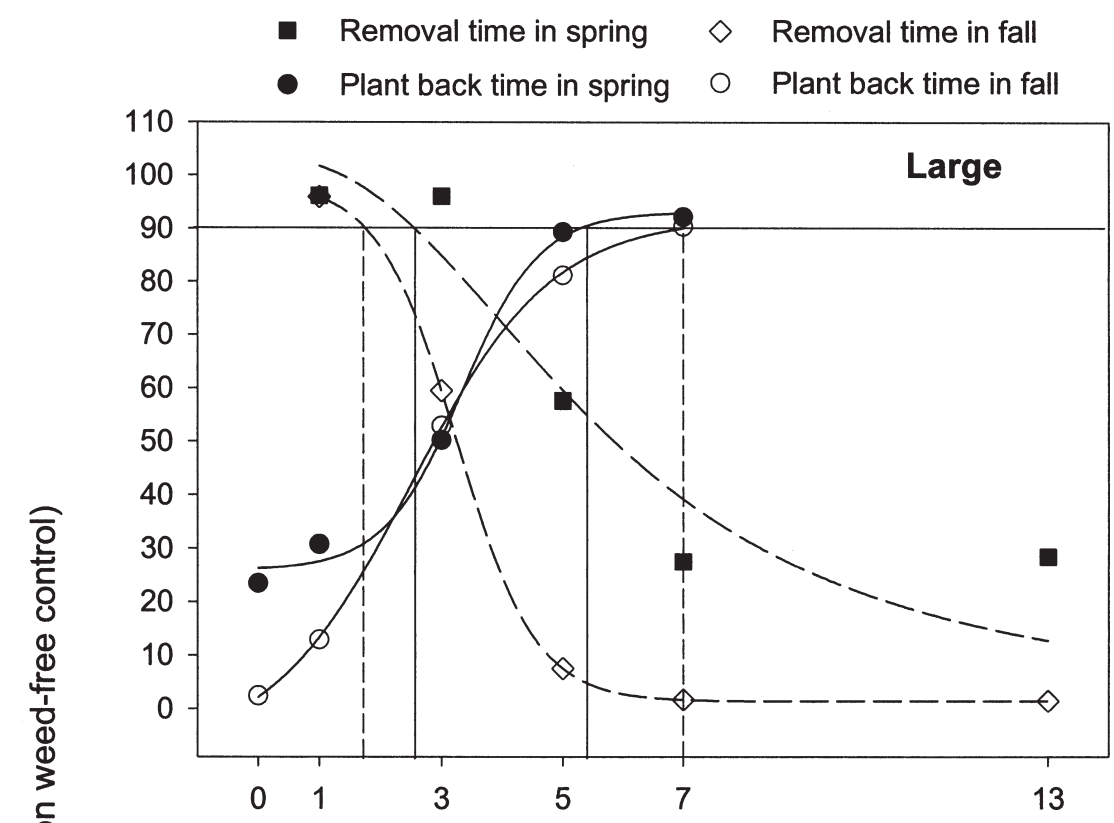

0
0
0
0
0
$\frac{1}{3}$
$\frac{2}{2}$
$\frac{0}{0}$
2
0
$\frac{1}{3}$
$\frac{1}{3}$
$\frac{2}{4}$

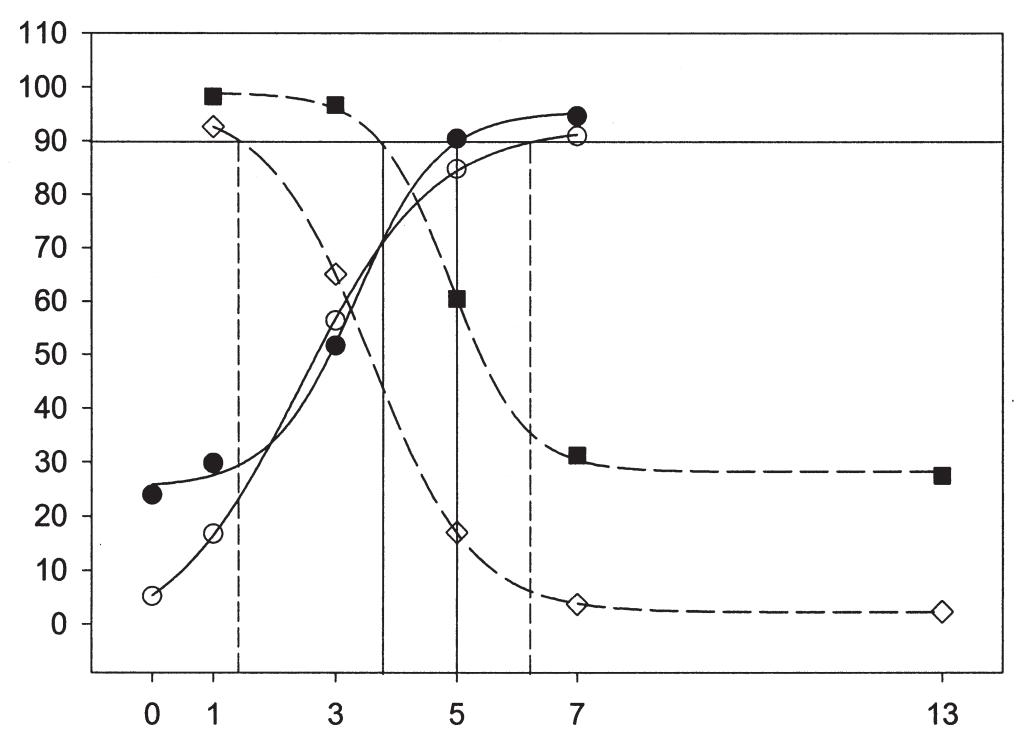

Weeks after pepper planting that nutsedge was removed or planted 
Table 2. Main effects of season (2000) and field on yellow nutsedge shoot height at 1,3, and 5 weeks after pepper transplanting (WAPT) in the nutsedge removal experiment. Significance also shown for interactions of season with field and season with nutsedge removal time.

\begin{tabular}{|c|c|c|c|c|c|c|}
\hline \multirow[b]{3}{*}{ Treatment } & \multicolumn{6}{|c|}{ Measuring times (WAPT) } \\
\hline & \multicolumn{2}{|c|}{1} & \multicolumn{2}{|c|}{3} & \multicolumn{2}{|c|}{5} \\
\hline & Nutsedge & Pepper & Nutsedge & Pepper & Nutsedge & Pepper \\
\hline Spring & 11 & 11 & 22 & 13 & 34 & 20 \\
\hline Fall & 16 & 8 & 41 & 12 & 60 & 18 \\
\hline Significance & $* * *$ & $* * *$ & & $* * *$ & & \\
\hline \multicolumn{7}{|l|}{ Field } \\
\hline Significance & NS & NS & & NS & & NS \\
\hline$S \times$ field & NS & NS & $*$ & NS & $* * *$ & NS \\
\hline $\mathrm{S} \times \mathrm{RT}^{\mathrm{z}}$ & --- & NS & --- & NS & --- & $* * *$ \\
\hline
\end{tabular}

${ }^{2}$ Removal time (RT) was not a factor affecting nutsedge growth because the nutsedge for each treatment (removal time) was planted into pepper plots at the same time. Therefore, statistics for the season by removal time interaction were only shown for pepper.

${ }_{\text {ns, }, * * * *}$ Effects were nonsignificant or significant at $P \leq 0.05$ or 0.001 , respectively, according to $\mathrm{F}$ tests. Statistics not shown for main effects when interactions were significant.

Table 3. Interaction of season (2000) and field on yellow nutsedge shoot height at 3 and 5 weeks after pepper transplanting (WAPT) in the nutsedge removal experiment.

\begin{tabular}{lccc}
\hline & \multicolumn{2}{c}{ Field } & \\
\cline { 2 - 3 } Season & 1 & 2 & Significance \\
\hline Nutsedge height 3 WAPT $(\mathrm{cm})$ & 22 & 21 & NS \\
$\quad$ Spring & 40 & 42 & NS \\
$\quad$ Fall & $* * *$ & $* * *$ & \\
$\quad$ Significance & 37 & 31 & $* * *$ \\
Nutsedge height 5 WAPT $(\mathrm{cm})$ & 58 & 62 & NS \\
$\quad$ Spring & $* * *$ & $* * *$ & \\
$\quad$ Fall & & & \\
$\quad$ Significance & & & \\
Ns,**** Effects within columns and rows were nonsignificant or significant at $P \leq 0.001$, respectively, accord- \\
ing to F tests.
\end{tabular}

sorted according to U.S. Department of Agriculture standards (U.S. Dept. of Agriculture, 1997) and the weight of U.S. Fancy, U.S. No.1, and U.S. No. 2 fruit determined. Fruit data for each grade were summed over the two harvests to obtain a total fruit weight. Large fruit yield was derived from the sum of U.S. Fancy and U.S. No. 1 fruit. Yields of U.S. Fancy, U.S. No. 1 and U.S. No. 2 fruit were summed to obtain marketable fruit yield.

Data were subjected to analysis of variance (ANOVA) using SAS (SAS Institute, 2000). Prior to ANOVA, pepper yields within each replication (block) were converted to percentage of fruit weight obtained with the full-season weed-free control (WFC) (Oliver, 1988). Fruit yield percentages were then regressed against nutsedge removal or planting times with a sigmoidal model (Hall et al., 1992; Knezevic et al., 2002). Resulting equations (Table 1) were used to calculate the critical nutsedge-free period for $10 \%$ yield loss [fruit weight percentage subtracted from 100 (yield percentage with full-season WFC)] based on the assumption that a Florida pepper grower could tolerate up to $10 \%$ pepper yield loss. Plant heights were analyzed and reported as actual values. Plant height responses to nutsedge planting or removal times were described with polynomial contrasts.

\section{Results and Discussion}

Nutsedge removal experiment. The response of large and marketable fruit yield to nutsedge removal time differed with season
(Fig. 1). Both large and marketable fruit weight percentages (of yield with WFC) declined more rapidly in fall than spring with increases in nutsedge interference time. Spring- and fall-grown pepper tolerated 3 and 2 weeks of nutsedge interference, respectively, with only a $10 \%$ reduction in large fruit yield. With full-season (13 weeks) nutsedge interference, large fruit yield declined by $87 \%$ in spring and $99 \%$ in fall.

For not more than $10 \%$ marketable yield loss, bell pepper tolerated 4 and 1 weeks of nutsedge interference in the spring and fall, respectively. In both seasons, there was little further yield loss with an increase in nutsedge interference time from 7 to $13 \mathrm{WAPT}$; however, yields with 7 to 13 weeks of nutsedge interference were reduced $70 \%$ in spring compared to $>90 \%$ in fall.

At 1 WAPT, nutsedge was taller in fall than spring while pepper was taller in spring than fall (Table 2). Pepper plants at 3 WAPT were $1 \mathrm{~cm}$ taller in spring than fall. Remaining season effects on plant heights were contained in interactions of season with field or nutsedge removal time as discussed below.

Plant heights at 1 WAPT were similar between fields (Table 2). At 3 WAPT, the effect of season on nutsedge shoot heights differed with field when shoots in both fields were taller in fall than spring (Table 3). Pepper plant height at 3 WAPT was similar between fields (Table 2). At 5 WAPT season interacted with field on nutsedge shoot height due to a greater height differential in field 2 than 1 (Table 3 ). In each field, however, nutsedge grew taller in fall than spring. Pepper plant height at 5 WAPT was similar between fields (Table 2), but height response to nutsedge removal time was influenced by season. Spring-season pepper plants at 5 WAPT were slightly taller with than without nutsedge competition, whereas pepper plant height in fall was unaffected by nutsedge removal time (data not shown). Plant height data collected later than 5 WAPT in each season were not reported because nutsedge leaves began to lay over.

Early-season crop/weed interaction influences final crop yields (William and Warren, 1975). As early as 1 WAPT, spring- and fall-season nutsedge shoots in the removal experiment were as tall or taller than pepper plants (Table 2). At 3 WAPT, nutsedge was much taller than pepper in both seasons. Furthermore, nutsedge grew taller (Tables 2 and 3 ) in fall than spring. Therefore, shading of pepper by nutsedge was probably more severe in fall than spring resulting in greater pepper yield losses to nutsedge interference in fall than spring (Fig. 1).

Nutsedge plant back experiment. Season interacted with yellow nutsedge planting time on fruit weight percentages (of yield with fullseason WFC; Fig.1). Large and marketable fruit weight percentages decreased more rapidly and to a greater extent in fall than spring as the nutsedge-free time was reduced from 7 to 0 WAPT. A nutsedge-free time of 5 weeks in spring and 7 weeks in fall was required for no more than $10 \%$ loss of large fruit. Seasonlong nutsedge interference reduced large pepper yields by $74 \%$ and $98 \%$ in spring and fall, respectively.

To prevent greater than $10 \%$ losses of marketable peppers, a nutsedge-free period of 5 and 6 weeks was required in spring and fall, respectively (Fig. 1). Full-season nutsedge interference reduced marketable yields by $74 \%$ in spring and $95 \%$ in fall.

The influence of nutsedge planting time on pepper plant height at 5 WAPT depended on season (Table 4). Spring-grown pepper plants competing with nutsedge grew taller than those with no nutsedge, but the heights of fall-season pepper plants were similar with or without nutsedge. Pepper plant height increased linearly in spring and quadratically in fall with an increase in nutsedge interference time from 
Table 4. Interactions of season (2000) with yellow nutsedge planting time on bell pepper plant height and of season with field and nutsedge planting time on nutsedge shoot height at 5 weeks after pepper transplanting (WAPT).

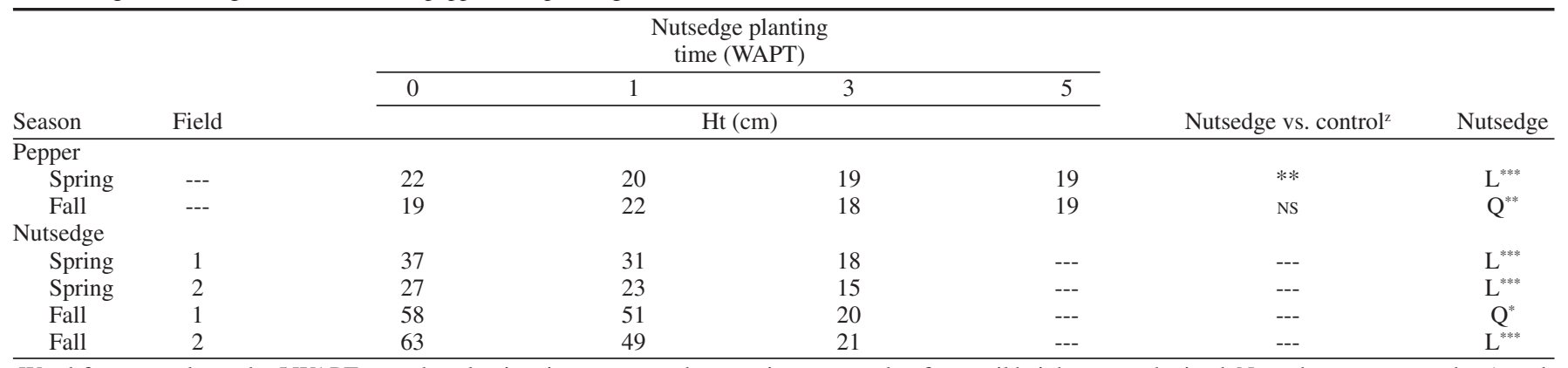

${ }^{2}$ Weed-free control was the 5 WAPT nutsedge planting time treatment because it was nutsedge-free until heights were obtained. Nutsedge vs. no nutsedge (weedfree control) effects on pepper height were tested with contrasts.

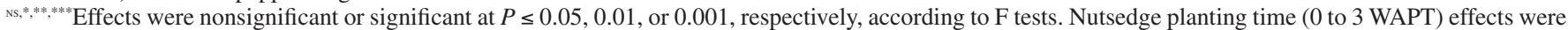
linear (L) or quadratic (Q) according to polynomial contrasts.

2 (nutsedge planted 3 WAPT) to 5 (nutsedge planted 0 WAPT) WAPT. These data suggest that pepper plants competed more effectively with nutsedge in spring than fall.

Nutsedge shoot height 5 WAPT was influenced by interacting factors of season, field, and nutsedge planting time (Table 4). Height in spring studies decreased linearly with an increase in the delay before nutsedge establishment from 0 to 3 WAPT, but nutsedge appeared taller in field 1 than 2. Fall-season height decreased quadratically and linearly in field 1 and 2 , respectively. Nutsedge planted 0 WAPT had grown taller than pepper in both seasons, but nutsedge shoots were much taller in fall than spring with the 0 and 1 WAPT planting times. Rapid early-season nutsedge growth in the fall may have reduced the ability of fall-grown pepper to compete with nutsedge.

The decline in nutsedge shoot height with longer delays in nutsedge planting (Table 4) was consistent with an increase in pepper yield percentages (of yield with full-season WFC) with increases in nutsedge-free time (Fig. 1). Pepper competitiveness against yellow nutsedge may be increased by controlling nutsedge plants before they overtop the pepper crop. Lanini and Le Strange (1991) found that summer annual weeds had minimal influence on bell pepper ('Jupiter') after pepper canopy establishment and fruit set.

Critical period. By plotting the maximum nutsedge interference (before removal) and minimum nutsedge-free (before planting) times in one figure, the critical nutsedge-free periods for pepper production were readily apparent. For example, the critical nutsedge-free period for large peppers in the spring was between 3 (maximum nutsedge interference time) and 5 (minimum nutsedge-free time) WAPT; in fall it was between 2 and 7 WAPT (Fig. 1). For marketable yield, the critical nutsedge-free period was between 4 and 5 WAPT in spring and 1 and 6 WAPT in fall.

Equations (Table 1) used to calculate the above-mentioned critical periods resulted in lines (Fig. 1) that fit the data well, as they explained $73 \%$ to $94 \%$ ( $r^{2}$ values) of variation within the data. Equations in Table 1 provided lines (Fig. 1) that were close to the mean value for each data point and were, thus, consistent with observed pepper yield patterns. Minimum predicted yield percentages, as indicated by equation parameters outlined in Table 1, were consistent with high large and marketable yield losses to nutsedge interference in full-season weedy controls (Fig. 1). Values (Table 1) close to $100 \%$ (of yield with WFC) for maximum predicted yield percentages were realistic because yields with nutsedge plants removed 1 WAPT or planted 7 WAPT were not expected to differ much from yields in WFC plots. Coefficient of variation $(\mathrm{CV})$ values for regression models indicated that, with the exception of the $\mathrm{CV}$ for large fruit production in the fall-season nutsedge removal experiment, values for individual replicates did not differ greatly from the means (data points shown in Fig. 1).

Variation within the data, although not unreasonable, likely accounted for the small differences in critical periods calculated for large vs. marketable fruit. A critical yellow nutsedge-free period from 3 to 5 WAPT in spring and 1 to 7 WAPT in fall would minimize the potential of underestimating the critical nutsedge-free period for any fruit grade.

The longer nutsedge-free period required by fall- than spring-grown pepper may have been due to higher early-season temperatures in fall than spring. Minimum daily air temperatures, averaged over the first three weeks of the season, was $10^{\circ} \mathrm{C}$ in spring compared to $21^{\circ} \mathrm{C}$ in fall (data not shown). Over the same period, maximum daily temperatures averaged $25^{\circ} \mathrm{C}$ in spring and $31^{\circ} \mathrm{C}$ in fall, and nutsedge grew more rapidly in fall than spring in two other experiments conducted at the same research unit as the present research (Motis et al., 2001; Motis et al., 2003). Yellow nutsedge plants assimilate $\mathrm{CO}_{2}$ through the $\mathrm{C}_{4}$ dicarboxylic acid photosynthetic pathway (Black et al., 1969; Wills et al., 1980). Assimilation of $\mathrm{CO}_{2}$ under high temperature and sunlight has been shown to be greater with the $\mathrm{C}_{4}$ than $\mathrm{C}_{3}$ (used by bell pepper plants) pathway (Black et al., 1969). Therefore, high early-season fall temperatures may have favored plant growth of nutsedge over bell pepper in the present research, resulting in stronger nutsedge competitiveness against pepper in fall than spring.

Interactions of season with field on nutsedge plant heights (Tables 3 and 4) suggest that field conditions were not uniform even though they were located on the same farm. In spring, the soil was sandier and much more difficult to keep moist in field 2 than 1 . Soil types in the fall were the same, but the soil in field 1 felt sandier to the touch than that in field 2 . The observation that the shortest nutsedge plants often occurred in the sandiest soil was consistent with the finding by Tumbleson and Kommedahl(1961) that yellow nutsedge tubers produced many more shoots when planted in peat or sandy silt loam than in sand. The fact that pepper plant height (Tables 2 and 4) and critical nutsedge-free periods (Fig. 1) for pepper production depended only on season suggests that nutsedge was more sensitive than pepper to varying climatic and soil conditions. This observation also suggests that the critical nutsedge-free periods for pepper were robust enough to be applied over other fields.

Critical weed-free periods are influenced by weed populations and emergence patterns (Martin etal., 2001; VanAckeretal., 1993).Yield losses of at least $70 \%$ (Fig. 1) with full-season yellow nutsedge interference in this research indicated that the initial nutsedge population with 45 tubers $/ \mathrm{m}^{2}$ was sufficient to provide strong nutsedge interference against pepper. Planting presprouted tubers precluded the possibility of late weed emergence and mimicked what would be expected to occur in commercial pepper fields where tubers that escape the effects of applied chemicals would likely sprout by crop establishment time. Therefore, it was not likely that the critical yellow nutsedge-free periods for bell pepper were underestimated.

Morales-Payan (1999) found that, for $10 \%$ yield loss of marketable field-grown tomato with an initial yellow nutsedge population of 50 plants $/ \mathrm{m}^{2}$, the critical yellow nutsedge-free period was from 3 to 6 WAPT regardless of season. A longer nutsedge-free period was expected for pepper than tomato because tomato produces a larger leaf canopy than pepper. This was the case for fall- but not spring-grown bell peppers. With full-season yellow nutsedge interference, however, marketable pepper yield losses of $>70 \%$ in both seasons (Fig. 1) exceeded that of $60 \%$ for marketable tomato in work by Morales-Payan (1999).

Knowledge of the critical weed-free period is needed for optimal timing of weed control practices including hand-weeding and herbicide applications. In the event a highly selec- 
tive post-emergence herbicide with strong yellow nutsedge activity becomes available for bell pepper, it would be necessary to time herbicide applications to eliminate yellow nutsedge interference within the appropriate critical nutsedge-free period. When climatic conditions and cultural practices are similar to those in this research, data in Fig. 1 and Table 1 may be used to calculate the critical yellow nutsedge-free periods for acceptable pepper yield loss (e.g., 10\%).

\section{Literature Cited}

Black, C.C., T.M. Chen, and R.H. Brown. 1969. Biochemical basis for plant competition. Weed Sci. 17:338-344.

Chase, C.A., T.R. Sinclair, D.G. Shilling, J.P. Gilreath, and S.J. Locascio. 1998. Light effects on rhizome morphogenesis in nutsedges (Cyperus spp.): implications for control by soil solarization. Weed Sci. 46:575-580.

Environmental Protection Agency. 1999. Protection of the stratospheric ozone: Incorporation of Montreal protocol adjustment for a 1999 interim reduction in Class I, Group VI controlled substances. Fed. Reg. 64:29240-29245.

Hall, MR., J.C. Swanton, and G.W. Anderson. 1992.
The critical period of weed control in grain corn (Zea mays). Weed Sci. 40:441-447.

Knezevic, S.Z., S.P. Evans, E.E. Blankenship, R.C. Van Acker, and J.L. Lindquist. 2002. Critical period for weed control: The concept and data analysis. Weed Sci. 50:773-786.

Lanini, W.T. and M. Le Strange. 1991. Low-input management of weeds in vegetable fields. Calif. Agr. 45:11-13.

Martin, S.G., R.C. Van Acker, and L.F. Friesen. 2001. Critical period of weed control in spring canola. Weed Sci. 49:326-333.

Maynard, D.N., G.J. Hochmuth, C.S. Vavrina, W.M. Stall, T.A. Kucharek, S.E. Webb, T.G. Taylor, and S.A. Smith. 2002. Pepper production in Florida, p. 217-224. In: S.M. Olson and D.N. Maynard (eds.). Vegetable production guide for Florida 2002-2003. Vance Publ. Corp. Lincolnshire, Ill.

Morales-Payan, J.P. 1999. Interference of purple and yellow nutsedges (Cyperus rotundus $\mathrm{L}$. and Cyperus esculentus L.) with tomato (Lycopersicon esculentum Mill.). PhD diss. Univ. Fla., Gainesville.

Motis, T.N., S.J.Locascio, and J.P. Gilreath. 2001. Yellow nutsedge interference effects on fruit weight of polyethylene-mulched bell pepper. Proc. Fla. State Hort. Soc. 114:268-271.

Motis, T.N., S.J. Locascio, J.P. Gilreath, and W.M. Stall. 2003. Season-long interference of yellow nutsedge (Cyperus esculentus) with polyethylenemulched bell pepper (Capsicum annиum). Weed Technol. 17: 543-549.

Oliver,L. 1988. Principles of weed threshold research. Weed Technol. 2:398-403.

SAS Institute. 2000. Proprietary software release 8.1. SAS Inst., Cary, N.C.

Stoller, E.W., D.P. Nema, and V.M. Bhan. 1972. Yellow nutsedge tuber germination and seedling development. Weed Sci. 21:76-81.

Tumbleson, M.E. and T. Kommedahl. 1961. Reproductive potential of Cyperus esculentus by tubers. Weeds 9:646-653.

U.S. Department of Agriculture. 1997. United States standards for grades of sweet peppers. U.S. Dept. Agr. Agr. Mktg. Serv., Wash., D.C.

Van Acker, C.R., C.J. Swanton, and S.F. Weise. 1993. The critical period of weed control in soybean [Glycine max (L.) Merr.]. Weed Sci. 41:194-200.

William, R.D. and G.F. Warren. 1975. Competition between purple nutsedge and vegetables. Weed Sci. 23:317-323.

Wills, G.D., R.E. Hoagland, and R.N. Paul. 1980. Anatomy of yellow nutsedge (Cyperus esculentus). Weed Sci. 28:432-437.

Witzig, J.D. and N.L.Pugh. 2001. Florida agricultural statistics: Vegetable summary 1999-2000. Fla. Agr. Stat. Serv., Orlando. 